\title{
Hydroxytamoxifen protects against oxidative stress in brain mitochondria
}

\author{
Paula I. Moreira ${ }^{\mathrm{a}, \mathrm{b}}$, José B. Custódio ${ }^{\mathrm{a}, \mathrm{c}}$, Catarina R. Oliveira ${ }^{\mathrm{a}, \mathrm{d}}$, Maria S. Santos ${ }^{\mathrm{a}, \mathrm{b}, *}$ \\ ${ }^{a}$ Center for Neuroscience of Coimbra, University of Coimbra, 3004-517 Coimbra, Portugal \\ ${ }^{\mathrm{b}}$ Department of Zoology_Faculty of Sciences and Technology, University of Coimbra, 3004-517 Coimbra, Portugal \\ ${ }^{\mathrm{c}}$ Laboratory of Biochemistry, Faculty of Pharmacy, University of Coimbra, 3004-517 Coimbra, Portugal \\ ${ }^{\mathrm{d}}$ Institute of Biochemistry, Faculty of Medicine, University of Coimbra, 3004-517 Coimbra, Portugal
}

Received 7 January 2004; accepted 19 March 2004

\begin{abstract}
This study evaluated the effect of hydroxytamoxifen, the major active metabolite of tamoxifen (synthetic, nonsteroidal antiestrogen drug), on the function of brain mitochondria. We observed that only high concentrations of hydroxytamoxifen (60 nmol/mg protein) induced a significant decrease in RCR, while ADP/O ratio remained statistically unchanged. Similarly, only the highest concentration of hydroxytamoxifen $(60 \mathrm{nmol} / \mathrm{mg}$ protein) affected the phosphorylative capacity of brain mitochondria, characterized by a decrease in the repolarization level and an increase in the repolarization lag phase. We observed that all the concentrations of hydroxytamoxifen tested $\left(7.5,15\right.$ and $30 \mathrm{nmol} / \mathrm{mg}$ protein) prevented lipid peroxidation induced by the oxidant pair ADP/Fe ${ }^{2+}$. Furthermore, through the analyses of calcium fluxes and mitochondrial transmembrane potential parameters, we observed that hydroxytamoxifen ( $30 \mathrm{nmol} / \mathrm{mg}$ protein) exerted some protection against pore opening, although in a less extension than that promoted by cyclosporin A, the specific inhibitor of the mitochondrial permeability transition pore. However, in the presence of hydroxytamoxifen plus cyclosporin A, the protection observed was significantly higher when compared with that induced by both agents alone.

These results support the idea that hydroxytamoxifen protects lipid peroxidation and inhibits the mitochondrial permeability transition pore in brain. Since numerous neurodegenerative diseases are intimately related with mitochondrial dysfunction resulting from lipid peroxidation and induction of mitochondrial permeability transition, among other factors, future therapeutical strategies could be designed taking in account this neuroprotective role of hydroxytamoxifen, which is pharmacologically much more potent and less toxic than its promoter tamoxifen.
\end{abstract}

(C) 2004 Elsevier Inc. All rights reserved.

Keywords: Brain; Calcium; Hydroxytamoxifen; Lipid peroxidation; Mitochondrial permeability transition; Neuroprotection

\section{Introduction}

Tamoxifen (TAM) is a non-steroidal estrogenic compound used for the treatment of breast cancer. It is a firstgeneration selective estrogen receptor modulator (SERM) and acts as an estrogen antagonist in mammary tissue but mimics the effects of estrogen in other tissues [1]. TAM undergoes extensive hepatic metabolism being hydroxytamoxifen (OHTAM) its major active metabolite and responsible for its antiestrogenic activity [2]. Besides their chemopreventing function, TAM and OHTAM, which are

\footnotetext{
* Corresponding author. Tel.: +351-239-834729; fax: +351-239-835812.

E-mail address: mssantos@ci.uc.pt (M.S. Santos).
}

extremelly lipophilic [3,4], induce multiple cellular effects, including antioxidant actions since they are strong intramembranous scavengers of peroxyl radicals [5].

TAM and OHTAM can penetrate the blood brain barrier and interact with several neuronal estrogen receptor-positive cell populations [6,7]. Previous studies in vitro [8] showed that OHTAM has a higher affinity for the estrogen receptor than TAM. Furthermore, OHTAM is 100- to 200times more potent $[9,10]$ and it is pharmacologically well tolerated [11] and less toxic to erythrocytes [12] and to sarcoplasmic reticulum calcium pump [13]. Dietze and collaborators [14] also reported that OHTAM, in contrast to TAM, do not induce apoptosis in p53(-) human mammary epithelial cells. Although most studies of TAM and its metabolites have been focused on its ability to compete 
with estrogens for binding to its receptors, several recent studies have described additional estrogen receptor-independent activities of TAM $[15,16]$.

Data from the literature point for a neuroprotective role associated to TAM and OHTAM being the study of TAM effects more explored. Previous studies have shown that TAM is effective in protecting brain tissue from rat models of reversible and permanent focal ischemia $[17,18]$ and suppress the $\mathrm{HO}^{\bullet}$ generation via dopamine efflux induced by $\mathrm{MPP}^{+}$[19]. O'Neill and Brinton [20] showed that both TAM and OHTAM attenuate the excitotoxic glutamateinduced intracellular $\mathrm{Ca}^{2+}$ rise.

It has become clear that mitochondria have a significant role to play not only in energy production, but also in cell death [21]. A potentially central factor in cell death in neurodegeneration is the mitochondrial permeability transition pore (MPTP) [22,23]. The MPTP is a phenomenon that is characterized by the opening of pores in the inner mitochondrial membrane and by its sensitivity to a very low concentration of cyclosporin A (CsA). $\mathrm{Ca}^{2+}$ and oxidative stress have long been known to favor the permeability transition [24].

Previous studies indicate that TAM [25] and OHTAM [26] are potent inhibitors of the MPTP in liver mitochondria. Furthermore, Hoyt et al. [27] reported that TAM could be an inhibitor of the MPTP in intact neurons. Our first goal was the evaluation of the impact of increasing concentrations of OHTAM $(15,30,60 \mathrm{nmol} / \mathrm{mg}$ protein) in the respiratory chain and oxidative phosphorylation system. For that purpose we analysed the respiratory indexes (RCR and ADP/O), mitochondrial transmembrane potential $\left(\Delta \Psi_{\mathrm{m}}\right)$, repolarization level, repolarization lag phase and ATP levels. The second part of this study was aimed to evaluate the protective effect of OHTAM in the lipid peroxidation induced by the pair $\mathrm{ADP} / \mathrm{Fe}^{2+}$ and in the induction of MPTP by $\mathrm{Ca}^{2+}$. Lipid peroxidation was evaluated by oxygen consumption and TBARS formation. MPTP induction was characterized by analyzing the mitochondrial $\Delta \Psi_{\mathrm{m}}$, calcium fluxes and glutathione content.

\section{Materials and methods}

\subsection{Materials}

Hydroxytamoxifen and Protease type VIII (Subtilisin Carlsberg) were obtained from Sigma (St. Louis, MO). Digitonin was obtained from Calbiochem (Merck Biosciences Ltd., Nottingham). All the other chemicals were of the highest grade of purity commercially available.

\subsection{Animals}

Male Wistar rats (3 months old) were housed in our animal colony (Laboratory Research Center, University Hospital, Coimbra, Portugal). They were maintained under controlled light (12 h day/night cycle) and humidity with free access to water (except in the fasting period) and powdered rodent chow (URF1-Charles River, France). Adhering to procedures approved by the Institutional Animal Care and Use Committee, the animals were sacrificed by cervical displacement and decapitation.

\subsection{Isolation of brain mitochondria}

Brain mitochondria were isolated from male Wistar by the method of Rosenthal et al. [28], with slight modifications, using $0.02 \%$ digitonin to free mitochondria from the synaptosomal fraction. In brief, one rat is decapitated, and the whole brain minus the cerebellum was rapidly removed, washed, minced, and homogenised at $4{ }^{\circ} \mathrm{C}$ in $10 \mathrm{ml}$ of isolation medium $(225 \mathrm{mM}$ mannitol, $75 \mathrm{mM}$ sucrose, $5 \mathrm{mM}$ Hepes, $1 \mathrm{mM}$ EGTA, $1 \mathrm{mg} / \mathrm{ml}$ bovine serum albumin, $\mathrm{pH}$ 7.4) containing $5 \mathrm{mg}$ of the bacterial protease. Single brain homogenates were brought to $30 \mathrm{ml}$ and then centrifuged at $2500 \mathrm{rpm}$ (Sorvall RC-5B Refrigerated Superspeed Centrifuge) for $5 \mathrm{~min}$. The pellet, including the fluffy synaptosomal layer, was resuspended in $10 \mathrm{ml}$ of the isolation medium containing $0.02 \%$ digitonin and centrifuged at $10,000 \mathrm{rpm}$ for $8 \mathrm{~min}$. The brown mitochondrial pellet without the synaptosomal layer was then resuspended again in $10 \mathrm{ml}$ of medium and recentrifuged at $10,000 \mathrm{rpm}$ for $10 \mathrm{~min}$. The mitochondrial pellet was resuspended in $300 \mu \mathrm{l}$ of resuspension medium (225 mM mannitol, $75 \mathrm{mM}$ sucrose, $5 \mathrm{mM}$ Hepes, $\mathrm{pH}$ 7.4). Mitochondrial protein was determined by the biuret method calibrated with bovine serum albumin [29].

\subsection{Mitochondrial respiration measurements}

Oxygen consumption of isolated mitochondria was monitored polarographically with a Clark oxygen electrode (YSI Model 5331, Yellow Springs Inst.) [30] connected to a suitable recorder in a $1 \mathrm{ml}$ thermostated waterjacketed closed chamber with magnetic stirring. The reactions were carried out at $30{ }^{\circ} \mathrm{C}$ in $1 \mathrm{ml}$ of the reaction medium (100 mM sucrose, $100 \mathrm{mM} \mathrm{KCl,} 2 \mathrm{mM} \mathrm{KH}_{2} \mathrm{PO}_{4}$, $5 \mathrm{mM}$ Hepes, $10 \mu \mathrm{M}$ EGTA, pH 7.4) with $0.6 \mathrm{mg}$ protein. The isolates were incubated with OHTAM for 2 min before succinate addition. ADP ( $125 \mathrm{nmol} / \mathrm{mg}$ protein $)$ was added after energization of mitochondria.

\subsection{Membrane potential $\left(\Delta \Psi_{m}\right)$ measurements}

The mitochondrial transmembrane potential was monitored by evaluating the transmembrane distribution of tetraphenylphosphonium $\left(\mathrm{TPP}^{+}\right)$with a $\mathrm{TPP}^{+}$-selective electrode prepared according to Kamo et al. [31] using an $\mathrm{Ag} / \mathrm{AgCl}_{2}$ electrode as reference.

Reactions were carried out in a chamber with magnetic stirring in $1 \mathrm{ml}$ of reaction medium supplemented with $3 \mu \mathrm{M} \mathrm{TPP}^{+}$. The experiments were started by adding $5 \mathrm{mM}$ 
succinate to mitochondria in suspension at $0.6 \mathrm{mg}$ protein/ $\mathrm{ml}$. Membrane potential was estimated from the decrease on $\mathrm{TPP}^{+}$concentration in the reaction medium as described elsewhere [32]. The isolates were incubated with OHTAM for $2 \mathrm{~min}$ before succinate addition. In the MPTP experiments, after a steady-state distribution of $\mathrm{TPP}^{+}$had been reached ( $\approx 2$ min of recording), $\mathrm{Ca}^{2+}$ was added and $\Delta \Psi_{\mathrm{m}}$ recorded.

\subsection{Analysis of ATP content}

At the end of the $\Delta \Psi_{\mathrm{m}}$ experiments, $250 \mu \mathrm{l}$ of each mitochondrial suspension were rapidly centrifuged at 14,000 rpm (Eppendorf Centrifuge 5415C) for $4 \mathrm{~min}$ with $0.3 \mathrm{M}$ perchloric acid. The supernatants were neutralised with $10 \mathrm{M} \mathrm{KOH}$ in $5 \mathrm{M}$ Tris and centrifuged at 14,000 rpm (Eppendorf Centrifuge 5415C) for $4 \mathrm{~min}$. The resulting supernatants were assayed for ATP by separation in a reverse-phase high performance liquid chromatography. The chromatography apparatus was a Beckman-System Gold, consisting of a 126 Binary Pump Model and 166 Variable UV detector controlled by a computer. The detection wavelength was $254 \mathrm{~nm}$, and the column was a Lichrospher 100 RP-18 (5 $\mu \mathrm{m})$ from Merck. An isocratic elution with $100 \mathrm{mM}$ phosphate buffer $\left(\mathrm{KH}_{2} \mathrm{PO}_{4}\right) \mathrm{pH} 6.5$ and $1.0 \%$ methanol was performed with a flow rate of $1 \mathrm{ml} / \mathrm{min}$. The required time for each analysis was $6 \mathrm{~min}$.

\subsection{Lipid peroxidation}

The extent of lipid peroxidation was evaluated by oxygen consumption using a Clark-type electrode (YSI Model 5331, Yellow Springs Inst.) in a closed glass chamber equipped with magnetic stirring, thermostated at $30{ }^{\circ} \mathrm{C}$, as described by Dinis et al. [33]. Reactions were started by the addition of $\mathrm{ADP} / \mathrm{Fe}^{2+}$. The changes in $\mathrm{O}_{2}$ tension were recorded in a potentiometric chart recorder and the oxygen consumption calculated assuming an oxygen concentration of $236 \mathrm{nmol} \mathrm{O}_{2} / \mathrm{ml}$. OHTAM was introduced in the incubation medium, containing mitochondria, $2 \mathrm{~min}$ before the addition of $\mathrm{ADP} / \mathrm{Fe}^{2+}$.

Lipid peroxidation was also determined by measuring thiobarbituric acid reactive substances (TBARS), using the thiobarbituric acid assay (TBA), according to a modified procedure described by Ernster and Nordenbrand [34]. The amount of TBARS formed was calculated using a molar coefficient of $1.56 \times 10^{5} \mathrm{~mol}^{-1} \mathrm{~cm}^{-1}$ and expressed as nmol TBARS/mg protein.

\subsection{Calcium fluxes}

Mitochondrial calcium fluxes were measured by monitoring the changes in $\mathrm{Ca}^{2+}$ concentration in the reaction medium using a calcium-selective electrode according to previously described procedures [32]. The reactions were conducted in an open vessel with magnetic stirring in $1 \mathrm{ml}$ of the reaction medium containing $100 \mathrm{mM}$ sucrose, $100 \mathrm{mM}$ $\mathrm{KCl}, 2 \mathrm{mM} \mathrm{KH}{ }_{2} \mathrm{PO}_{4}, 10 \mu \mathrm{M}$ EGTA, 5 mM Hepes ( $\mathrm{pH} 7.4$ ), with $2 \mu \mathrm{M}$ rotenone. Mitochondria $(0.8 \mathrm{mg} / \mathrm{ml})$ were energized with $5 \mathrm{mM}$ succinate after $1 \mathrm{~min}$ of $\mathrm{Ca}^{2+}$ addition. $30 \mathrm{nmol}$ OHTAM/mg protein, $0.85 \mu \mathrm{M} \mathrm{CsA}$ and $2 \mu \mathrm{g} / \mathrm{ml}$ oligomycin plus $1 \mathrm{mM}$ ADP were added to the reaction medium 2 min prior $\mathrm{Ca}^{2+}$ addition. In CsA plus OHTAM condition, CsA was added after mitochondria energization.

\subsection{Glutathione content}

Reduced (GSH) and oxidized (GSSG) glutathione were determined with fluorescence detection after reaction of the supernatant of the $\mathrm{H}_{3} \mathrm{PO}_{4} /$ EDTA- $\mathrm{NaH}_{2} \mathrm{PO}_{4}$ or $\mathrm{H}_{3} \mathrm{PO}_{4} /$ $\mathrm{NaOH}$ deproteinized mitochondria solution, respectively, with $o$-phthalaldehyde (OPT), pH 8.0, according to Hissin and Hilf [35]. In brief, at the end of the $\Delta \Psi_{\mathrm{m}}$ experiments, $500 \mu \mathrm{l}$ of each mitochondrial suspension were rapidly centrifuged at 50,000 rpm (Beckman, TL-100 Ultracentrifuge) for $30 \mathrm{~min}$ with $1.5 \mathrm{ml}$ phosphate buffer $(100 \mathrm{mM}$ $\mathrm{NaH}_{2} \mathrm{PO}_{4}, 5 \mathrm{mM}$ EDTA, $\mathrm{pH} 8.0$ ) and $500 \mu \mathrm{H}_{3} \mathrm{PO}_{4} 2.5 \%$. For GSH determination $100 \mu$ of the supernatant were added to $1.8 \mathrm{ml}$ phosphate buffer and $100 \mu \mathrm{l}$ OPT. After mixing and incubation at room temperature for $15 \mathrm{~min}$, the solution was transferred to a quartz cuvette and the fluorescence was measured at $420 \mathrm{~nm}$. For GSSG determination $250 \mu \mathrm{l}$ of the supernatant were added to $100 \mu \mathrm{l}$ of $N$ ethylmaleymide and incubated at room temperature for $30 \mathrm{~min}$. After the incubation $140 \mu \mathrm{l}$ of the mixture were added to $1.76 \mathrm{ml} \mathrm{NaOH} \mathrm{(100} \mathrm{mM)} \mathrm{buffer} \mathrm{and} 100 \mu \mathrm{l}$ OPT. After mixing and incubation at room temperature for $15 \mathrm{~min}$, the solution was transferred to a quartz cuvette and the fluorescence was measured at 420 and $350 \mathrm{~nm}$ emission and excitation wavelength, respectively (slits 5, 5). The GSH and GSSG contents were determined from comparisons with a linear reduced or oxidized glutathione standard curve, respectively.

\subsection{Statistical analysis}

Results are presented as mean \pm S.E.M. of the indicated number of experiments. Statistical significance was determined by using the one-way ANOVA test for multiple comparisons, followed by the post hoc Tukey-Kramer test or by the unpaired two-tailed Student's $t$-test.

\section{Results}

\subsection{Effect of OHTAM in brain mitochondrial respiration}

Respiratory control ratio ( $\mathrm{RCR}$ ) is the ratio between mitochondrial respiration states 3 (consumption of oxygen in the presence of substrate and ADP) and 4 (consumption of oxygen after ADP has been consumed). Only the higher 

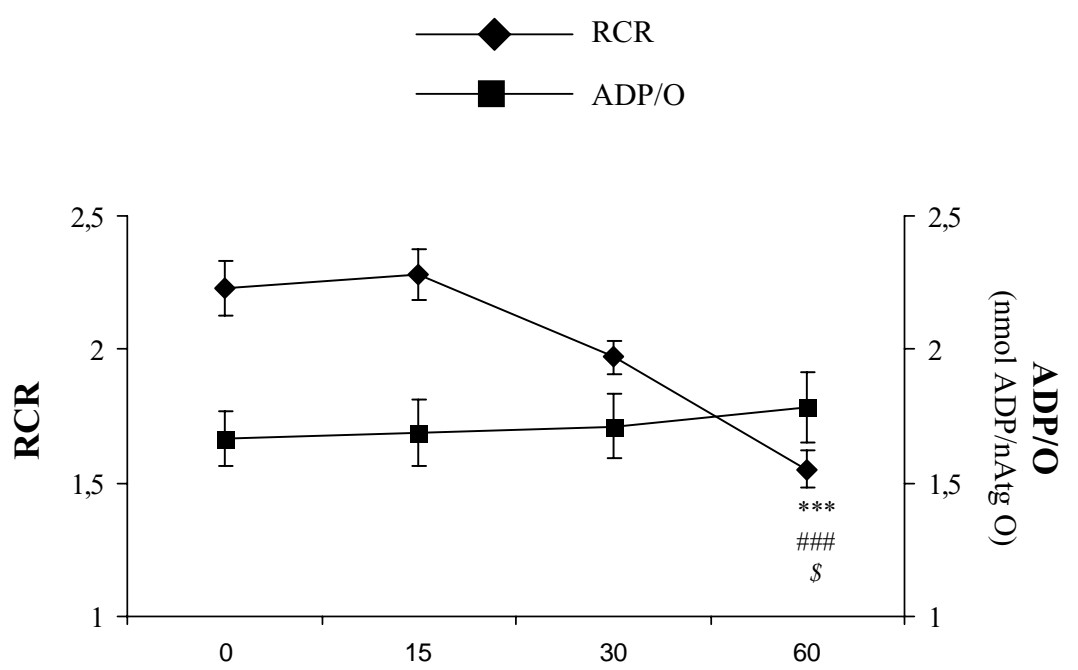

nmol OHTAM/mg protein

Fig. 1. Effect of OHTAM in respiratory control indexes (RCR and ADP/O ratio) of brain mitochondria. Freshly isolated brain mitochondria (0.6 mg) in $1 \mathrm{ml}$ of the standard medium supplemented with $2 \mu \mathrm{M}$ rotenone were energized with $5 \mathrm{mM}$ succinate. Isolates were incubated with $\mathrm{OHTAM}$ for $2 \mathrm{~min}$, at $30{ }^{\circ} \mathrm{C}$, before mitochondria energization. Results are presented as mean \pm S.E.M. of six independent experiments. $(* * *) P<0.001$, when compared with mitochondria in control condition. (\#\#\#) $P<0.001$, when compared with mitochondria incubated with $15 \mathrm{nmol}$ OHTAM $/ \mathrm{mg}$ protein. (\$) $P<0.05$, when compared with mitochondria incubated with $30 \mathrm{nmol}$ OHTAM/mg protein.

concentration of OHTAM (60 $\mathrm{nmol} / \mathrm{mg}$ protein) induced a significant decrease on RCR when compared with control condition $(30.49 \% \pm 1.35)$ as well as when compared with $15 \mathrm{nmol} \mathrm{OHTAM} / \mathrm{mg}$ protein $(32.11 \% \pm 1.16)$ and $30 \mathrm{nmol}$ OHTAM/mg protein $(21.40 \% \pm 0.40)$ (Fig. 1).

$\mathrm{ADP} / \mathrm{O}$ ratio, an indicator of oxidative phosphorylation efficiency, is expressed by the ratio between the amount of ADP added and the oxygen consumed during the state 3 of respiration. This parameter remained statistically unchanged in all the conditions studied (Fig. 1).

\subsection{Effect of OHTAM in brain mitochondrial transmembrane potencial $\left(\Delta \Psi_{m}\right)$, repolarization level, repolarization lag phase and ATP content}

The mitochondrial transmembrane potential $\left(\Delta \Psi_{\mathrm{m}}\right)$ is fundamental for the phenomenon of oxidative phosphorylation, the conversion of ADP to ATP via ATP synthase.
Mitochondrial respiratory chain pumps $\mathrm{H}^{+}$out of the mitochondrial matrix across the inner mitochondrial membrane. The $\mathrm{H}^{+}$gradient originates an electrochemical potential $(\Delta p)$ resulting in a $\mathrm{pH}(\Delta \mathrm{pH})$ and a voltage gradient $\left(\Delta \Psi_{\mathrm{m}}\right)$ across the mitochondrial inner membrane. As shown in Table $1, \Delta \Psi_{\mathrm{m}}$ remained unchanged in all the conditions tested. However, the repolarization level (capacity of mitochondria to reestablish the $\Delta \Psi_{\mathrm{m}}$, after ADP phosphorylation) decreased significantly in the presence of $60 \mathrm{nmol}$ OHTAM/mg protein when compared with all the other conditions tested (Table 1). Accordingly, the repolarization lag phase (time necessary for ADP phosphorylation) increased significantly in the presence of the highest OHTAM concentration tested.

Concerning the ATP content, we did not observe any significant alteration promoted by OHTAM. Although the presence of $60 \mathrm{nmol}$ OHTAM/mg protein slowed the oxidative phosphorylation capacity of brain mitochondria

Table 1

Effect of OHTAM in the mitochondrial oxidative phosphorylation system (mitochondrial transmembrane potential $\left(\Delta \Psi_{\mathrm{m}}\right)$, repolarization level, repolarization lag phase and ATP content)

\begin{tabular}{lcccc}
\hline & Control & OHTAM $(15 \mathrm{nmol} / \mathrm{mg}$ prot $)$ & OHTAM $(30 \mathrm{nmol} / \mathrm{mg}$ prot $)$ & OHTAM (60 nmol/mg prot) \\
\hline$\Delta \Psi_{\mathrm{m}}(-\mathrm{mV})$ & $186.6 \pm 1.83$ & $184.9 \pm 2.36$ & $183.5 \pm 2.51$ & $175.9 \pm 3.06$ \\
Repolarization level $(-\mathrm{mV})$ & $157.5 \pm 2.18$ & $152.9 \pm 1.69$ & $151.0 \pm 1.98$ & $139.6 \pm 2.29 * * * \#, \$ \$$ \\
Repolarization lag phase (min) & $0.558 \pm 0.05$ & $0.588 \pm 0.051$ & $0.738 \pm 0.036$ & $0.922 \pm 0.071^{* * * * \# \#}$ \\
ATP content (nmol/mg protein) & $285.9 \pm 17.75$ & $279.5 \pm 12.85$ & $243.5 \pm 13.33$ & $272.4 \pm 19.69$ \\
\hline
\end{tabular}

The oxidative phosphorylation parameters were evaluated using freshly isolated brain mitochondria $(0.6 \mathrm{mg})$ in $1 \mathrm{ml}$ of the reaction medium supplemented with $3 \mu \mathrm{M} \mathrm{TPP}^{+}$and $2 \mu \mathrm{M}$ rotenone and energized with $5 \mathrm{mM}$ succinate.

${ }^{* * * * *} P<0.001$, statistically significant when compared to control condition.

\#\# $P<0.01$, statistically significant when compared to $15 \mathrm{nmol}$ OHTAM $/ \mathrm{mg}$ protein.

$\$ \$ P<0.01$, statistically significant when compared to $30 \mathrm{nmol}$ OHTAM/mg protein. Data shown represent mean \pm S.E.M. from six independent experiments. 
(increase in repolarization lag phase and decrease in repolarization level) they were capable to phosphorylate all the ADP added to mitochondrial suspension.

\subsection{Effect of OHTAM on lipid peroxidation: oxygen consumption and TBARS formation}

The oxygen consumption and TBARS assay were used to determine the level of lipid peroxidation induced by $\mathrm{ADP} / \mathrm{Fe}^{2+}$. The maximal values of oxygen consumption (Fig. 2A) and TBARS formation (Fig. 2B), observed at $15 \mathrm{~min}$ of peroxidation, were $172.8 \pm 23.79 \mathrm{nmol} / \mathrm{mg}$ protein and $22.75 \pm 3.53 \mathrm{nmol}$ TBARS/mg protein,
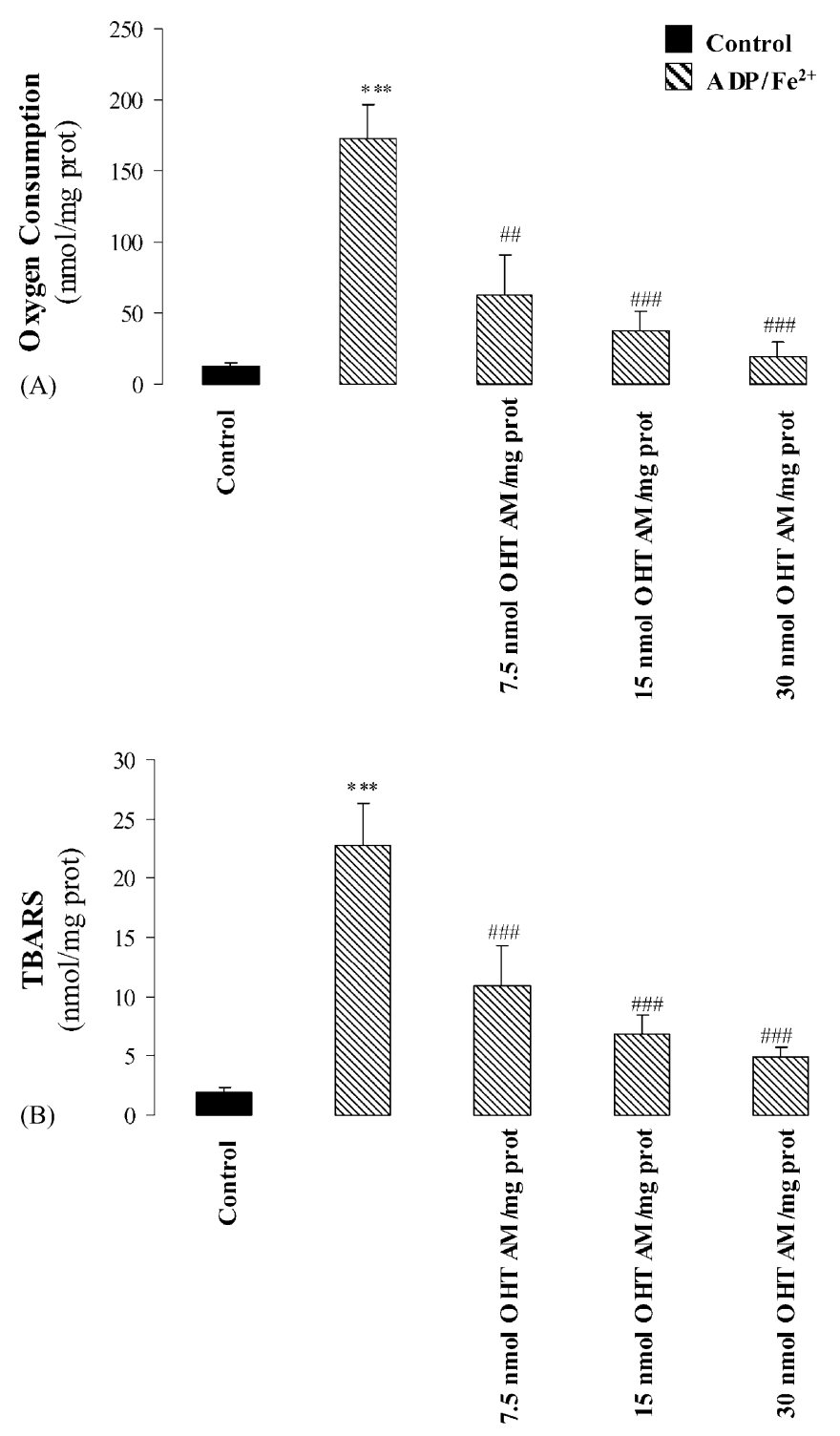

Fig. 2. Effect of OHTAM on lipid peroxidation: oxygen consumption (A) and TBARS formation (B). Freshly isolated brain mitochondria were incubated at $0.6 \mathrm{mg}$ protein $/ \mathrm{ml}$ under standard conditions as described in Section 2. Isolates were pre-incubated with OHTAM for $2 \mathrm{~min}$, at $30^{\circ} \mathrm{C}$, before the addition of ADP-Fe ${ }^{2+}$. Results are presented as mean \pm S.E.M. of six independent experiments. (*) $P<0.05$, when compared with mitochondria in control condition. (\#\#\#) $P<0.001$; (\#\#) $P<0.01$; (\#) $P<0.05$; when compared with mitochondria incubated with $30 \mu \mathrm{M} \mathrm{Ca}^{2+}$. respectively. Inhibition of oxygen consumption and TBARS formation was observed in the presence of all the concentrations of OHTAM tested (Fig. 2A and B). Although a concentration-dependent protection was observed, the presence of $7.5 \mathrm{nmol} \mathrm{OHTAM} / \mathrm{mg}$ protein afforded a clear protection being the extension of lipid peroxidation not statistically different when compared with the other concentrations of OHTAM tested as well as when compared with the control condition.

\subsection{Effect of OHTAM on the mitochondrial permeability transition pore (MPTP): $\Delta \Psi_{m}$ and calcium fluxes}

The mitochondrial potential $\left(\Delta \Psi_{\mathrm{m}}\right)$ drop is a typical phenomenon that follows the induction of MPTP. In control conditions (Fig. 3A), the addition of $5 \mathrm{mM}$ succinate produced an $\Delta \Psi_{\mathrm{m}}$ of $\approx 185 \mathrm{mV}$ (negative inside mitochondria), corresponding to the respiratory state 4 . Then, the first pulse of $10 \mu \mathrm{M} \mathrm{Ca}^{2+}$ led to a rapid depolarization (decrease of $\Delta \Psi_{\mathrm{m}}$ ) followed by a small repolarization (recover of $\Delta \Psi_{\mathrm{m}}$ ). The depolarization was due to the entry of $\mathrm{Ca}^{2+}$ into the electronegative mitochondrial matrix, followed by the efflux of $\mathrm{H}^{+}$in an attempt to restore the $\Delta \Psi_{\mathrm{m}}$. However, a second and third pulse of $10 \mu \mathrm{M}$ $\mathrm{Ca}^{2+}$ led to a total depolarization of mitochondria. Mitochondria can tolerate some amount of $\mathrm{Ca}^{2+}$, but ultimately their capacity to adapt to $\mathrm{Ca}^{2+}$ loads is overwhelmed and mitochondria depolarize completely due to a profound change in the inner membrane permeability. Since the mitochondrial collapse of $\Delta \Psi_{\mathrm{m}}$, associated to $\mathrm{Ca}^{2+}$ overload, is related with MPTP opening, experiments were performed to further confirm the induction of the MPTP opening by studying the $\mathrm{Ca}^{2+}$ retention by energized mitochondria. Fig. 4 shows that isolated brain mitochondria incubated with $100 \mathrm{nmol} \mathrm{Ca}{ }^{2+} / \mathrm{mg}$ protein in the presence of $2 \mathrm{mM}$ phosphate and energized with succinate, rapidly accumulate $\mathrm{Ca}^{2+}$ from the medium and, after a slow release of some of the accumulated $\mathrm{Ca}^{2+}$, they were able to continue to accumulate $\mathrm{Ca}^{2+}$, thus retaining part of the $\mathrm{Ca}^{2+}$ present in the medium. In the presence of $50 \mathrm{nmol}$ $\mathrm{Ca}^{2+} / \mathrm{mg}$ protein mitochondria retained a large portion of this cation, however in the presence of $150 \mathrm{nmol} \mathrm{Ca}{ }^{2+} / \mathrm{mg}$ protein mitochondria became unable to retain the accumulated $\mathrm{Ca}^{2+}$ due to MPTP opening (Fig. 4A).

These effects on calcium accumulation could be prevented in the presence of $0.85 \mu \mathrm{M}$ CsA and $1 \mathrm{mM}$ ADP plus $2 \mu \mathrm{g} / \mathrm{ml}$ oligomycin. Although both agents contributed for a higher capacity of mitochondria to accumulate $\mathrm{Ca}^{2+}$, the protection exerted by ADP plus oligomycin was more effective than that exert by CsA (Figs. 3B, C and 4). The presence of $30 \mathrm{nmol}$ OHTAM/mg protein ( $2 \mathrm{~min}$ preincubation) exerted some protection against mitochondrial membrane depolarization and calcium release, by increasing the capacity of mitochondria to acumulate $\mathrm{Ca}^{2+}$ (Figs. 3B and 4B). Additionally, the presence of $0.85 \mu \mathrm{M}$ cyclosporin $\mathrm{A}$ (CsA) (specific inhibitor of MPTP) 
A. Control

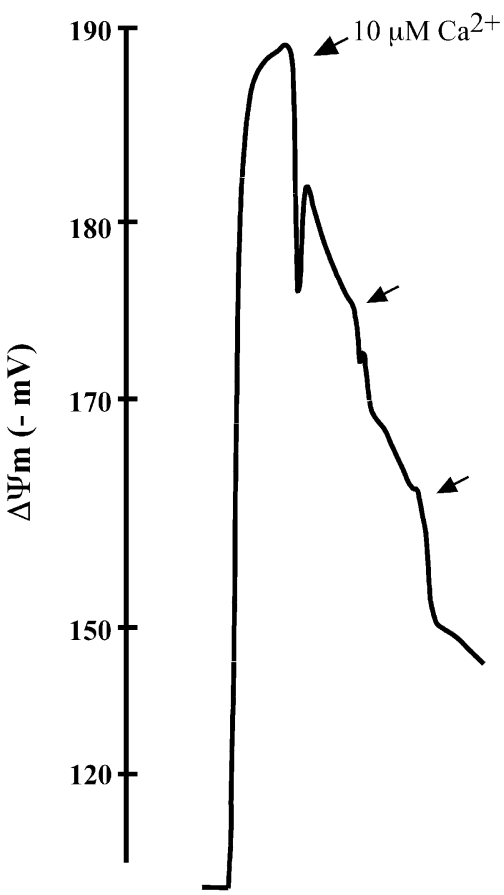

B. OHTAM

C. CsA



D. OHTAM + CsA

Fig. 3. Effect of OHTAM on mitochondrial transmembrane potential depolarization: permeability transition pore induction. Freshly isolated brain mitochondria $\left(0.6 \mathrm{mg}\right.$ ) in $1 \mathrm{ml}$ of the standard medium supplemented with $3 \mu \mathrm{M}$ TPP ${ }^{+}$and $2 \mu \mathrm{M}$ rotenone were energized with $5 \mathrm{mM}$ succinate. (A) Control condition; (B) $30 \mathrm{nmol} \mathrm{OHTAM} / \mathrm{mg}$ protein; (C) $0.85 \mu \mathrm{M}$ CsA; (D) $30 \mathrm{nmol} \mathrm{OHTAM} / \mathrm{mg}$ protein plus $0.85 \mu \mathrm{M}$ CsA. Isolates were pre-incubated with OHTAM and/or CsA for $2 \mathrm{~min}$ before mitochondria energization with succinate. $\mathrm{Ca}^{2+}(3 \times 10 \mu \mathrm{M})$ was added 1.5 min after mitochondria energization. The traces are typical of six independent experiments.

added 2 min prior to $\mathrm{Ca}^{2+}$, afforded a clear protection of mitochondria (Figs. 3C and 4). However, in the presence of both agents, $30 \mathrm{nmol}$ OHTAM/mg protein and $0.85 \mu \mathrm{M}$ $\mathrm{CsA}$, the capacity of mitochondria to accumulate $\mathrm{Ca}^{2+}$ increased significantly being mitochondria more resistant to $\mathrm{Ca}^{2+}$ addition and, consequently, to MPTP induction (Figs. 3D and 4B).

\subsection{Effect of OHTAM on the mitochondrial glutathione content}

Theoretically, the opening of MPTP is stimulated by the alteration of GSH redox status ( $-\mathrm{SH} \rightarrow-\mathrm{SS}-)$. We observed that $\mathrm{Ca}^{2+}$ induced a decrease in GSH (reduced glutathione) which was reversed in the presence of $30 \mathrm{nmol}$ OHTAM/mg protein and/or CsA. However, GSSG (oxidized glutathione) did not change in all the conditions studied (Fig. 5). The decrease induced by $\mathrm{Ca}^{2+}$ in GSH was confirmed by the significant decrease of GSH/GSSG ratio being this decrease reverted by the presence of $30 \mathrm{nmol}$ OHTAM /mg protein and/or CsA (Fig. 5).

\section{Discussion}

Several evidences from the literature indicate that mitochondria have a significant role to play not only in routine energy metabolism, but also in cell death [21]. Neurons are structures extremely susceptible to mitochondrial dysfunction since about $90 \%$ of the energy required by these cells is provided by mitochondria. In this order, the search of new compounds capable to protect mitochondria against toxic and/or stressful agents has become an important goal for many scientists working in this research area.

In this study the effect of OHTAM in brain mitochondrial function was evaluated. We observed that only higher concentrations of OHTAM $(60 \mathrm{nmol} / \mathrm{mg}$ protein) promote a decrease in respiratory chain and oxidative phosphorylation efficiencies (Fig. 1, Table 1). In accordance, Cardoso et al. [36] observed that OHTAM decreases the respiratory coefficient and the ADP/O ratio of liver mitochondria in a concentration-dependent way. However, this depression of respiratory indexes was significant for concentrations above $40 \mathrm{nmol}$ OHTAM/mg protein. Furthermore, they also observed that concentrations of OHTAM > $40 \mathrm{nmol} / \mathrm{mg}$ protein increases the lag phase of repolarization and decreases the rate of repolarization. Similarly, we observed a decrease on repolarization level and an increase on repolarization lag phase although these alterations occurred in the presence of higher OHTAM concentrations (60 nmol OHTAM/mg protein) (Table 1). The discrepancies in the concentrations of OHTAM in both studies are probably due to the different type of mitochondria used. 


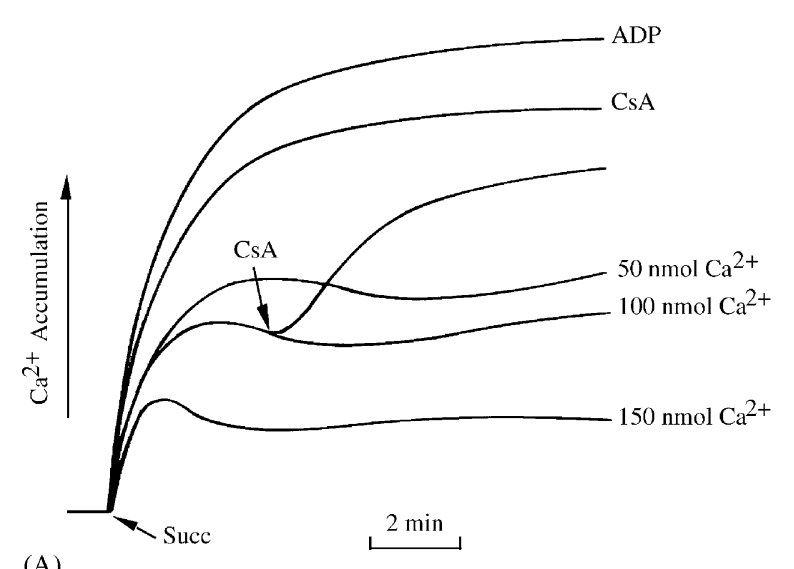

(A)

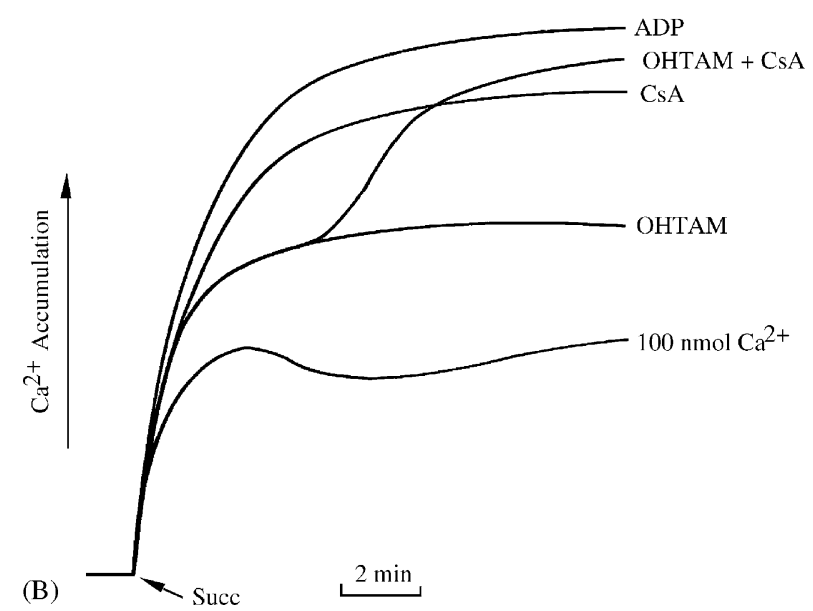

Fig. 4. Effect of OHTAM on calcium fluxes. Mitochondria were incubated at $0.8 \mathrm{mg}$ protein $/ \mathrm{ml}$ under standard conditions as described in Section 2. Standard medium was supplemented with $\mathrm{Ca}^{2+} 1 \mathrm{~min}$ before mitochondria energization with $5 \mathrm{mM}$ succinate. $30 \mathrm{nmol}$ OHTAM/mg protein, $0.85 \mu \mathrm{M}$ CsA and $2 \mu \mathrm{g} / \mathrm{ml}$ oligomycin plus $1 \mathrm{mM}$ ADP were added to the reaction medium 2 min prior $\mathrm{Ca}^{2+}$ addition. In CsA plus OHTAM condition, CsA was added after mitochondria energization. The uptake and release of sequestered $\mathrm{Ca}^{2+}$ by mitochondria were monitored as described in Section 2. The traces are typical of six independent experiments.

The existence of tissue-specific differences in mitochondria properties has been described [37,38].

Our results indicate that although a decrease in oxidative phosphorylation efficiency occurs in the presence of high concentrations of OHTAM, it do not interfere with ATP content of brain mitochondria (Table 1). Recently, Cardoso et al. [39] showed that only concentrations of OHTAM above $60 \mathrm{nmol} / \mathrm{mg}$ protein decrease ATP content of liver mitochondria.

However, OHTAM has shown to be a powerful antioxidant, protecting brain mitochondria against $\mathrm{ADP} / \mathrm{Fe}^{2+}$ induced lipid peroxidation. Our results show that OHTAM exert a potent antioxidant action since $7.5 \mathrm{nmol}$ OHTAM/ $\mathrm{mg}$ protein was sufficient to reduce oxygen consumption (Fig. 2A) and TBARS levels (Fig. 2B) to values similar to those found in control condition (basal values). It has been described that OHTAM is a scavenger of peroxyl radicals in several cells and systems. OHTAM inhibits lipid per- oxidation in sarcoplasmic reticulum membranes [5] and $\mathrm{Fe}^{3+}$-ascorbate-induced lipid peroxidation in rat liver microsomes [40]. Furthermore, the ability of TAM and OHTAM to inhibit $\mathrm{Cu}^{2+}$-induced peroxidation of lowdensity lipoprotein has been suggested to contribute to the putative cardioprotective effects of these antiestrogens [41]. Raghvendra and coworkers [42] demonstrated that estrogen and tamoxifen metabolites protect smooth muscle cell membrane phospholipids against peroxidation via a non-estrogen receptor-dependent mechanism. A study from O'Neill et al. [43] showed that raloxifene (estrogen receptor modulator) at low concentrations $(50 \mathrm{ng} / \mathrm{ml})$ induces a significant neuroprotection against $\beta$-amyloid-, $\mathrm{H}_{2} \mathrm{O}_{2}$ - and glutamate-induced toxicity. However, the same study showed that raloxifene exerts partial estrogen agonist action in the absence of $17 \beta$-estradiol whereas in its presence raloxifene exerted a mixed estrogen agonistantagonist effect. Similarly, Lei et al. [44] found that estrogen and raloxifene can influence glial-mediated inflammatory pathways and possibly protecting against age- and disease-related neuropathology. However, there are some evidences that TAM and OHTAM are associated with intracellular oxidative stress $[45,46]$. These discrepancies can be due to differences in the concentrations of TAM and OHTAM and/or experimental models used. Indeed, some animal studies indicate the existence of dose-related biphasic effects of estradiol $[47,48]$. Some effects are lost at higher concentrations $[47,48]$, whereas others require high doses [49]. These dose-related effects could be taken as an advantage to possibly dissociate some activities in the target tissue. It is possible that a similar picture occurred with antiestrogen compounds.

Since previous studies [26] demonstrated the inhibitory effect of OHTAM on MPTP induction, we tested the effect of OHTAM on $\mathrm{Ca}^{2+}$-induced MPTP of isolated brain mitochondria. MPTP causes a non-selective permeabilization of the inner mitochondrial membrane typically promoted by the accumulation of excessive quantities of $\mathrm{Ca}^{2+}$ ions and stimulated by a variety of compounds or conditions [24]. In this study, the classic inductor $\mathrm{Ca}^{2+}$ was used to induce MPTP opening (Figs. 3 and 4). $\mathrm{Ca}^{2+}$ uptake is concentration-dependent, with higher concentrations leading to a lower amount of $\mathrm{Ca}^{2+}$ being accumulated by mitochondria, indicating a continuous cycling of $\mathrm{Ca}^{2+}$ due to MPTP induction. The pore opening allows the equilibration of ions and respiratory substrate between cytosol and mitochondrial matrix leading to a reduction on $\Delta \Psi_{\mathrm{m}}$ [50], which is linked to depletion of GSH [51]. Indeed, mitochondrial pore induction is intimately associated with GSH and protein thiol redox state [52]. Glutathione is the most abundant antioxidant in the cell. Regeneration of GSH from GSSG occurs in matrix. Continued regeneration of GSH requires NADPH, which in turn requires transhydrogenation of $\mathrm{NADP}^{+}$and NADH. In our study, we observed that $\mathrm{Ca}^{2+}$ induced a significant decrease in GSH/GSSG ratio due to a decrease in GSH 

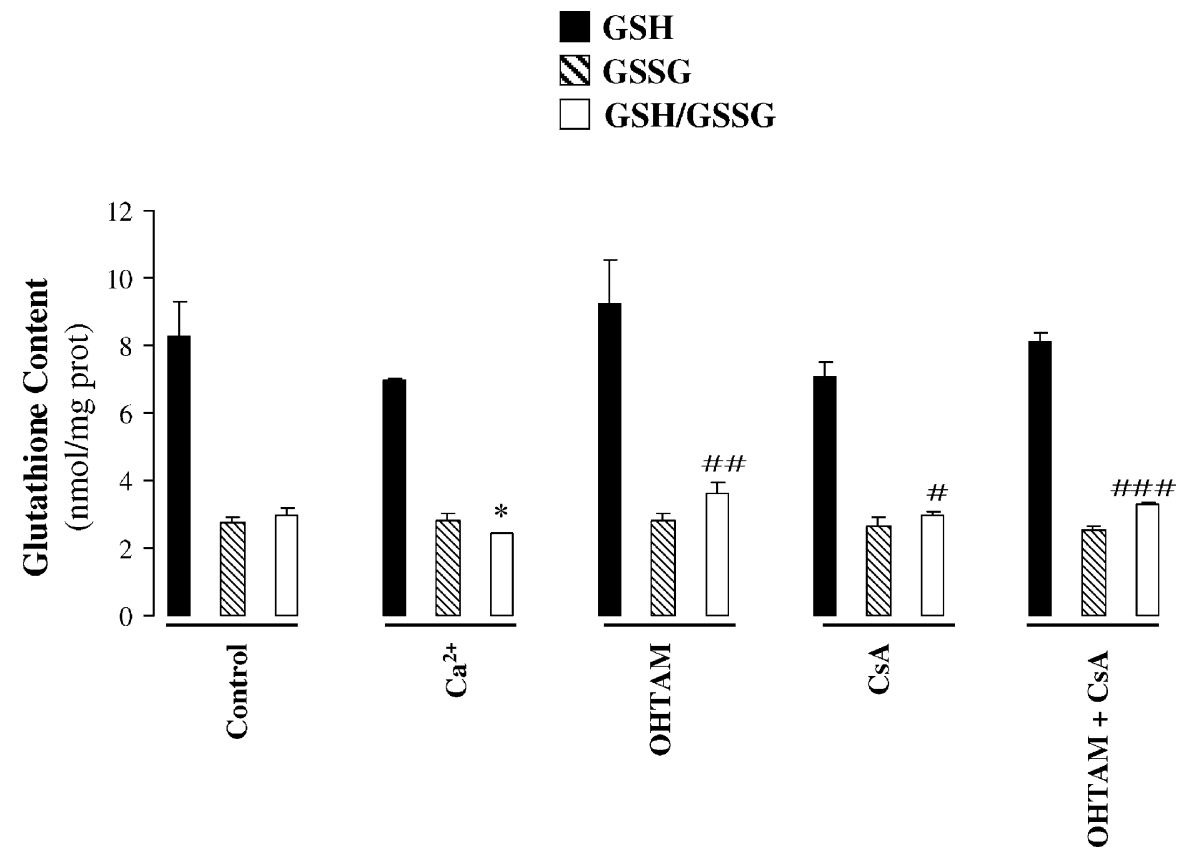

Fig. 5. Effect of OHTAM on mitochondrial GSH content. Freshly isolated brain mitochondria $(0.6 \mathrm{mg})$ in $1 \mathrm{ml}$ of the standard medium supplemented with $2 \mu \mathrm{M}$ rotenone were energized with $5 \mathrm{mM}$ succinate. Isolates were pre-incubated with OHTAM and/or CsA for 2 min, at $30^{\circ} \mathrm{C}$, before mitochondria energization. $\mathrm{Ca}^{2+}$ was added after mitochondria energization. Results are presented as mean \pm S.E.M. of six independent experiments.

content since no alteration in GSSG content was observed (Fig. 5). Similarly, Custódio et al. [25] showed that the loss of matrix GSH from liver mitochondria is attributed to its release to the medium since no GSSG was detected in any of the reactions and since the total GSH (intra and extramitochondrial) did not change. So, the depletion of GSH was solely due to the efflux from the permeabilized mitochondria, which was prevented by cyclosporin A and hydroxytamoxifen (Fig. 5).

The presence of $30 \mathrm{nmol}$ OHTAM/mg protein exerted some protection against $\mathrm{Ca}^{2+}$-induced MPTP opening (Figs. 3B and 4B). Our results are supported by the observations of Morkuniene et al. [53] that OHTAM prevented calcium-induced loss of cytochrome $c$ from heart mitochondria. In our study, CsA does not give a total protection against MPTP induction, however, it increases the capacity of brain mitochondria to accumulate $\mathrm{Ca}^{2+}$ (Figs. 3C and 4). Simpson et al. [54] observed that TAM exerted a CsA-like action on SH-SY5Y neuroblastoma mitochondria. Similarly, Cardoso et al. [26] observed that $20 \mu \mathrm{M}$ OHTAM caused a total inhibition of $\mathrm{Ca}^{2+}$-induced depolarization of succinate-energized liver mitochondria similar to that exerted by CsA. As discussed previously, due to tissue-specific differences in mitochondria pore properties [37], the ability of both agents, OHTAM and CsA, to protect against MPTP induction differs significantly between different types of mitochondria. The effect of CsA on the ability of brain mitochondria to accumulate $\mathrm{Ca}^{2+}$ was only moderate when compared with the effects described for CsA on muscle or liver mitochondria $[38,55]$. Similar effects of CsA were also reported on cell lines [56] and neuronal primary cultures [57]. Another study performed in a neuronal primary culture showed that mitochondrial depolarization induced by glutamate was partially inhibited by TAM [27]. Interestingly, $30 \mathrm{nmol} \mathrm{OHTAM} / \mathrm{mg}$ protein plus CsA exerted a higher protection against MPTP opening (Fig. 3D and 4B) when compared with the protection exerted by each agent alone (Fig. 3B, C and 4). These results indicate that the effects of both agents are not additive, suggesting that they act at different places on mitochondrial pore complex. The most plausible hypothesis concerning MPTP inhibition by CsA is that cyclophilin D binding to the matrix side of the MPTP favors its opening and that CsA indirectly causes pore closure through unbinding of cyclophilin D after formation of the CsA-cyclophilin complex [58]. In turn, MPTP inhibition by OHTAM may be due to its antioxidant properties [5]. This hypothesis is supported by our results that show that OHTAM exerts potent antioxidant effects against lipid peroxidation (Fig. 2A and $\mathrm{B})$.

Our results support the idea that the neuroprotective role of OHTAM is primarily due to its antioxidant-like actions. However, we cannot rule out its capacity in MPTP inhibition, especially in the presence of CsA, exacerbating its inhibitory effect in MPTP induction. In this order, new therapeutic strategies can be designed for the treatment of neurodegenerative disorders where mitochondrial dysfunction, resulting among other factors from lipid peroxidation and MPTP induction, may have a determinant role in neuronal cell degeneration and death. 


\section{Acknowledgments}

This work was supported by FCT (Portuguese Research Council). Paula Moreira is the recipient of a grant SFRH/ $\mathrm{BD} / 5320 / 2001$.

\section{References}

[1] Sato M, Rippy MK, Bryant HU. Raloxifene, tamoxifen, nafoxidine, or estrogen effects on reproductive and nonreproductive tissues in ovariectomized rats. FASEB J 1996;10:905-12.

[2] Mauvais-Jarvis P, Baudot N, Castaigne D, Banzet P, Jutten F. Trans 4hydroxytamoxifen concentration and metabolism after local percutaneous administration to human breast. Cancer Res 1986;46:1521-5.

[3] Custódio JBA, Almeida LM, Madeira VMC. A reliable and rapid procedure to estimate drug partioning in biomembranes. Biochem Biophys Res Commun 1991;176:1079-85.

[4] Custódio JBA, Almeida LM, Madeira VMC. The active metabolite hydroxytamoxifen of the anticancer drug tamoxifen induces structural changes in membranes. Biochim Biophys Acta 1993;1153:308-14.

[5] Custódio JBA, Dinis TCP, Almeida LM, Madeira VMC. Tamoxifen and hydroxytamoxifen as intramembraneous inhibitors of lipid peroxidation. Evidence for peroxyl radical scavenging activity. Biochem Pharmacol 1994;47:1989-98.

[6] Jordan VC, Bamj RR, Brown RR, Gosdon B, Santos MA. Determination and pharmacology of a new hydroxylated metabolite of tamoxifen observed in patient sera during therapy for advanced breast cancer. Cancer Res 1983;43:1446-50.

[7] Lien EA, Solheim E, Ueland PM. Distribution of tamoxifen and its metabolites in rat and human tissues during steady-state treatment. Cancer Res 1991;51:4837-44.

[8] Robertson DW, Katzenellenbogen JA, Long DJ, Rorke EA, Katzenellenbogen BS. Tamoxifen antiestrogens. A comparison of the activity, pharmacokinetics, and metabolic activation of the cis and trans isomers of tamoxifen. J Steroid Biochem 1982;16:1.

[9] Jordan VC, Koch R, Langan S, McCague R. Ligand interaction at the estrogen receptor to program antiestrogen action: a study with nonsteroidal compounds in vitro. Endocrinology 1998;122:1449-54.

[10] Osborne CK, Wiebe VJ, McGuire WL, Ciocca DR, DeGregorio MW. Tamoxifen and the isomers of 4-hydroxytamoxifen in tamoxifen resistant tumours from breast cancer patients. J Clin Oncol 1992; 10:304-10.

[11] Sauvez F, Drouin DS, Attia M, Bertheux H, Forster R. Cutaneously applied 4-hydroxytamoxifen is not carcinogenic in female rats. Carcinogenesis 1999;20:843-50.

[12] Cruz Silva MM, Madeira VMC, Almeida LM, Custódio JBA. Hydroxytamoxifen interaction with human erythrocyte membrane and induction of permeabilization and subsequent hemolysis. Toxicol In Vitro 2001;15:615-22.

[13] Custódio JBA, Almeida LM, Madeira VMC. The effect of the anticancer drug tamoxifen and hydroxytamoxifen on the calcium pump of isolated sarcoplasmic reticulum vesicles. Toxicol In Vitro 1996;10: 523-31.

[14] Dietze EC, Caldwell LE, Grupin SL, Mancini M, Deewaldt VL. Tamoxifen but not 4-hydroxytamoxifen initiates apoptosis in p53(-) normal human mammary epithelial cells by inducing mitochondrial depolarization. J Biol Chem 2001;276:5384-94.

[15] Perry RR, Kang Y, Greaves B. Effects of tamoxifen on growth and apoptosis of estrogen-dependent and -independent human breast cancer calls. Ann Surg Oncol 1995;2:238-45.

[16] Fattman CL, An B, Sussman L, Dou QP. p53-independent dephosphorylation and cleavage of retinoblastoma protein during tamoxifen-induced apoptosis in human breast carcinoma cells. Cancer Lett 1998;130:103-13.
[17] Kimelberg HK, Feustel PJ, Jin Y, Paquette J, Boulos A, Keller Jr RW, et al. Acute treatment with tamoxifen reduces ischemic damage following middle cerebral artery occlusion. Neuroreport 2000;11: 2675-9.

[18] Kimelberg HK, Jin Y, Charniga C, Feustel PJ. Neuroprotective activity of tamoxifen in permanent focal ischemia. J Neurosurg 2003;99: $138-42$.

[19] Obata T. Environmental estrogen-like chemicals and hydroxyl radicals induced by MPTP in the striatum: a review. Neurochem Res 2002; 27:423-31.

[20] O’Neill KJ, Brinton RD, Tamoxifen attenuates glutamate and estrogen-potentiated calcium signaling in hippocampal neurons. In: Program No.272.10 Abstract Viewer/Itinerary Planner. CD-ROM. Washington, DC: Society for Neuroscience; 2002.

[21] Bossy-Wetzel E, Green DR. Apoptosis: checkpoint at the mitochondrial frontier. Mutat Res 1999;434:243-51.

[22] Kim KJ, Jang YY, Han ES, Lee CS. Modulation of brain mitochondrial membrane permeability and synaptosomal $\mathrm{Ca}^{2+}$ transport by dopamine oxidation. Mol Cel Biochem 1999;201:89-98.

[23] Brustovetsky N, Dubinsky JM. Dual responses of CNS mitochondria to elevated calcium. J Neurosci 2000;20:103-13.

[24] Zoratti M, Szabo I. The mitochondrial permeability transition. Biochem Biophys Acta 1995;1241:139-76.

[25] Custódio JBA, Moreno AJM, Wallace KB. Tamoxifen inhibits induction of the mitochondrial permeability transition by $\mathrm{Ca}^{2+}$ and inorganic phosphate. Toxicol Appl Pharmacol 1998;152:5384-94.

[26] Cardoso CMP, Almeida LM, Custódio JBA. 4-Hydroxytamoxifen is a potent inhibitor of the mitochondrial permeability transition. Mitochondrion 2002;1:485-95.

[27] Hoyt KR, McLaughlin BA, Higgins Jr DS, Reynolds IJ. Inhibition of glutamate-induced mitochondrial depolarization by tamoxifen in cultured neurons. J Pharmacol Exp Ther 2000;293:480-6.

[28] Rosenthal RE, Hamud F, Fiskum G, Varghese PJ, Sharpe S. Cerebral ischemia and reperfusion: prevention of brain mitochondrial injury by lidoflazine. J Cereb Blood Flow Metab 1987;7:752-8.

[29] Gornall AG, Bardawill CJ, David MM. Determination of serum proteins by means of the biuret reaction. J Biol Chem 1949;177: $751-66$.

[30] Estabrook RE. Mitochondrial respiratory control and the polarographic measurement of ADP/O ratios. Methods Enzymol 1967;10:41-7.

[31] Kamo N, Muratsugu M, Hongoh R, Kobatake V. Membrane potential of mitochondria measured with an electrode sensitive to tetraphenylphosphonium and relationship between proton electrochemical potential and phosphorylation potential in steady state. J Membr Biol 1979;49:105-21.

[32] Moreno AJM, Madeira VMC. Mitochondrial bioenergetics as affected by DTT. Biochem Biophys Acta 1991;1060:166-74.

[33] Dinis TC, Madeira VMC, Almeida L. Action of phenolic derivatives (Acetominophen, salicylate, and 5-aminosalicylate) as inhibitors of membrane lipid peroxidation and as peroxyl radical scavengers. Arch Biochem Biophys 1994;315:161-9.

[34] Ernster L, Nordenbrand K. Microsomal lipid peroxidation. Methods Enzymol 1967;10:574-80.

[35] Hissin PJ, Hilf R. A fluorometric method for determination of oxidized and reduced glutathione in tissues. Anal Biochem 1976;74:714-26.

[36] Cardoso CMP, Moreno AJM, Almeida LM, Custódio JBA. 4-Hydroxytamoxifen induces slight uncoupling of mitochondrial oxidative phsphorylation system in relation to the deleterious effects of tamoxifen. Toxicology 2002;179:221-32.

[37] Berman SB, Watkins SC, Hastings TG. Quantitative biochemical and ultrastructural comparison of mitochondrial permeability transition in isolated brain and liver mitochondria: evidence for reduced sensitivity of brain mitochondria. Exp Neurol 2000;164:415-25.

[38] Moreira PI, Santos MS, Moreno A, Rego AC, Oliveira C. Effect of amyloid beta-peptide on permeability transition pore: a comparative study. J Neurosci Res 2002;69:257-67. 
[39] Cardoso CMP, Moreno AJM, Almeida LM, Custódio JBA, Comparison of the changes in adenine nucleotides of rat liver mitochondria induced by tamoxifen and hydroxytamoxifen. Toxicol In Vitro 2003.

[40] Wiseman H, Cannon M, Arnstein HRV, Halliwell B. Mechanism of inhibiton of lipid peroxidation by tamoxifen and 4-hydroxytamoxifen introduced in liposomes. Similarity to cholesterol and ergosterol. FEBS Lett 1990;274:107-10.

[41] Wiseman H, Paganga G, Rice-Evans C, Halliwell B. Protective actions of tamoxifen and 4-OH-tamoxifen against oxidative damage to human low-density lipoproteins: a mechanism accounting for the cardioprotective action of tamoxifen. Biochem J 1993;292:635-8.

[42] Dubey RK, Tyurina YY, Tyurin VA, Gillespie DG, Branch RA, Jackson EK, et al. Estrogen and tamoxifen metabolites protect smooth muscle cell membrane phospholipids against peroxidation and inhibit cell growth. Circ Res 1999;84:229-39.

[43] O'Neill K, Chen S, Brinton RD. Impact of the selective estrogen receptor modulator, raloxifene, on neuronal survival and outgrowth following toxic insults associated with aging and Alzheimer's disease. Exp Neurol 2004;185:63-80.

[44] Lei DL, Long JM, Hengemihle J, O'Neill J, Manaye KF, Ingram DK, et al. Effects of estrogen and raloxifene on neuroglia number and morphology in the hippocampus of aged female mice. Neuroscience 2003;121:659-66.

[45] Duthie SJ, Melvin WT, Burke MD. Drug toxicity mechanisms in human hepatoma HepG2 cells: cyclosporin A and tamoxifen. Xenobiotica 1995;25:1151-64.

[46] Ye Q, Bodell WJ. Production of 8-hydroxy-2'-deoxyguanosine in DNA by microsomal activation of tamoxifen and 4-hydroxytamoxifen. Carcinogenesis 1996;17:1747-50.

[47] Abolfathi Z, Di Paolo T. Modulation of dopamine receptor agonist binding sites by cations and estradiol in intact pituitary and 7315a tumours. Biochem Pharmacol 1991;42:2163-9.

[48] Levesque D, Di Paolo T. Modulation by estradiol and progesterone of the GTP effect on striatal D-2 dopamine receptors. Biochem Pharmacol 1993;45:723-33.
[49] Green PS, Bishop J, Simpkins JW. 17 Alpha-estradiol exerts neuroprotective effects on SK-N-SH cells. J Neurosci 1997;17: $511-5$.

[50] Bernardi P, Vassanelli S, Veronese P, Colonna R, Szabo I, Zoratti M. Modulation of the mitochondrial permeability transition pore. Effect of protons and divalent cations. J Biol Chem 1992;267: 2934-9.

[51] Macho A, Hirsch T, Marzo I, Marchetti P, Dallaporta B, Susin SA, et al. Glutathione depletion is an early and calcium elevation is a late event of thymocyte apoptosis. J Immunol 1997;158:4612-9.

[52] Le Quoc D, Le Quoc K, Gaudemer Y. Energy-dependent variation of thiol groups reactivity or accessibility in rat liver mitochondria, revealed by measurements of labelled thiol reagents incorporation. Biochem Biophys Res Commun 1976;68:106-13.

[53] Morkuniene R, Jekabsone A, Borutaite V. Estrogens prevent calciuminduced release of cytochrome $\mathrm{c}$ from heart mitochondria. FEBS Lett 2002;521:53-6.

[54] Simpson PB, Woollacott AJ, Moneer Z, Rand V, Seabrook GR. Estrogen receptor ligand affect mitochondrial activity SH-SY5Y human neuroblastoma cells. Neuroreport 2002;13:957-60.

[55] Kristián T, Gertsch J, Bates TE, Siesjö BK. Characteristics of the calcium triggered mitochondrial permeability transition in nonsynaptic brain mitochondria: effect of cyclosporin A and ubiquinone 0. J Neurochem 2000;74:1999-2009.

[56] Murphy AN, Bredesen DE, Cortopassi G, Wang E, Fiskum G. Bcl-2 potentiates the maximal calcium uptake capacity of neuronal cell mitochondria. Proc Natl Acad Sci USA 1996;93:9893-8.

[57] Dubinsky JM, Levi Y. Calcium-induced activation of the mitochondrial permeability transition in hippocampal neurons. J Neurosci Res 1998;53:728-41.

[58] Connern CP, Halestrap AP. Chaotropic agents and increased matrix volume enhance binding of mitochondrial cyclophilin to the inner mitochondrial membrane and sensitize the mitochondrial permeability transition to $\left[\mathrm{Ca}^{2+}\right]$. Biochemistry 1996;35:817280 . 